\title{
Moments and Significance of Balkan Diplomacy at the Start of the Twentieth Century
}

\author{
Cotirlet Paul-Claudiu \\ University of Bucharest
}

\begin{abstract}
Historically, the Balkan Peninsula is marked as an area where the Ottoman Empire made its influence known. The notion of Balkan space is often thought of in a negative way, being associated with the so called „Powder Keg of Europe”. At the start of the nineteenth century, the peninsula was divided by the Ottoman and Habsburg empires. One century later, the same lands are divided up by six states. No less than 11 wars and countless armed conflicts were necessary in order to get to this result. For the Europeans that lived at the start of the last century, the Balkans represented a terra incognita, a particular area, slightly explored, constantly avoided, carrying the burden of violence. A territory filled with terror and endless strife, conjuring up unpleasant images: political instability, secret societies, and atrocities. This study shows the manner in which diplomacy tried to play a major role in this region's stability through its fundamental concepts (summits, international conferences, parliamentary diplomacy, the international activities of transnational and subnational entities, the unofficial diplomacy of non-governmental elements, as well as the work put in by numerous international civil employees). Also, it will incline towards the last phase of the balance of power system, more specifically on its ending through the first Balkan war. Diplomacy is often mistaken for "foreign policy” or „external relations”, but the terms are not synonymous. Diplomacy is the main, yet not the only tool of foreign policy. On the other hand, foreign policy establishes goals, provides strategies and enforces measures that must be used in order for complete those goals. Diplomacy is therefore the main substitute for using violence, force or subversive tactics; it is the peaceful way in which two or more states can negotiate a common foreign policy.
\end{abstract}

Keywords: Southeast Europe, Nationalism, Borders, Conflicts, Balance of Power.

\section{INTRODUCTION}

The Balkan Peninsula, partially considered a unit of transition between the middle and southern parts of Europe, occupies an area of 468.000 square $\mathrm{km}$, being the third largest peninsula in Europe (Cotet, 1967). From a geographical point of view, this region is represented as a whole, being located between the Danube (the northern border), the Black 
Sea, Mediterranean Sea and Adriatic Sea, making up the eastern, southern and western limits of the peninsula. The Ionian Sea, opening towards the Mediterranean, represents the south-western border, while the Aegean Sea, located in the south-east, advances along the line made up by the Dardanelles and Bosphorus straits all the way towards the Black Sea. Throughout time, there have been many different opinions regarding marking the northern border, different authors also including regions from the north of the Danube. Geographically, it could be said that the peninsula stopped at the Danube. But from an economical, political and cultural point of view, the great river had to be passed (Bulei, 2011).

In the modern age, the foreign affairs domain is reserved for a small group of decisional factors, being led by a monarch, who considers that diplomatic affairs can be managed through his personal relationships with other monarchs (Young, 2006). This is the reason for which regal visits have been perceived, during this age, as a true diplomatic event, that could contribute to clarifying certain differences that came up between two states (McLean, 2001).

The political map of the start of the twentieth century shows us that monarchy keeps its positions, or conquers new ones, once other state entities show up. It's no surprise that during this period, all diplomatic acts are being done in the name of the sovereign. Although in theory it was available to everyone, in reality, diplomacy during those times was part of a elitist community, that had its own customs and rules (Cain, 2012). It was a world ruled by the aristocratic principle. Diplomacy remains an aristocratic profession, as long as the active involvement in the central system of governmental policies is an aristocratic occupation as well (Jones, 1983).

"We prefer to be ruled by an aristocrat, even if we know he is incompetent, because we know very well what he'll do, and what he won't" (Young, 1921)

The predominance of aristocracy among the diplomatic corps was obvious: $40 \%$ in the UK, $65 \%$ in Italy, $45 \%$ in France, almost entirely in Russia and the Austro-Hungarian Empire (between 1860 Inquiry and 1914). Constantinople and Bucharest were the two capitals 2016/1 from this region that were the most demanded and interesting for the diplomats of the Great Powers. During their stay on the shore of the Bosphorus, a lot of ambassadors saw this experience as an opportunity to propel to a higher position inside the state they represented. On the other side were Athens, Belgrade, Cetinje and Sofia, where life wasn't as attractive and did not represent as many advantages as the aforementioned capital cities.

The economic and financial leaders of the world changed the power and wealth balance at a global scale, thus we are left with inequality between diplomatic representation in the West and 
the Balkans. Only the Great Powers have representation through ambassadors. They tend to have between 7 representations, like in the case of the Ottoman and Czarist empires, and 10 embassies, like the Austro-Hungarian Empire or the French Republic. The majority of these embassies are opened in Europe, and especially the Western World, but we do have cases where diplomacy "crosses the ocean" (Germany, France, The Czarist Empire and Great Britain have embassies in Washington).

The south-eastern space limits itself from a diplomatic representation perspective, only to The Old Continent. Thus, in 1909 the Serbian Kingdom sustains diplomatic relationships with 14 states, of which only two are not European (USA and Persia) (Vesnitsh,1909). In Romania's case, we have 13 states, only one being situated outside of the continent, in Egypt. Both Bulgaria and Montenegro have diplomatic representation only in Europe, in 11 countries.

European diplomacy at the start of the twentieth century is based on the "Concert of Europe" principle, or Congress System principle, as it was later called. This principle consisted of the balance of power that existed in Europe starting with the Wien Peace Congress that marked the end of the Napoleon Wars (1815). To understand this balance, we must first discuss power. Power, like love, is easier to experience than to define or measure. Power is the ability to achieve your means and objectives. More specifically, it is the capacity to influence others and to obtain the results that you want (Nye Jr., 2005).

The balance of power system had divided into 5 stages of evolution: between 1815 and 1822, the states have conjugated their actions, meeting frequently in order to appease disputes and maintaining a balance. Once nationalism and democratic revolutions start to rise, the balance of power enters a new stage between 1822 and 1854. The occurrence of wars (Crimean war or the Unification war in Italy) has led this balance system process to a turning point. Once this moment had passed, the balance of power manifested under the face of the great Bismarck, who tried to push France over the borders into imperialist adventures, and to stray the attention of his allied partners form his lost province (Alsace and Lorena) in 1870-1890. Bismarck's predecessors didn't show the same flexibility in the international arena and this caused the end of the balance of power starting with the Balkan Wars between 1890 and 1912.

The European Congress made it so that Europe would live the longest period of peace ever known. For 40 years there hadn't been even one war between the Great Powers, and after the Crimean War in 1854, no war took place for another 60 years (Kissinger, 2003). After the Congress of Wien, the relationship between the balance 
of power and a common sentiment of legitimacy was expressed into two documents: The Quadruple Alliance, made up of Great Britain, Prussia, Austria and Russia, and the Holly Alliance, which was limited to three of the so called Western Courts: Prussia, Austria and Russia. But all these alliances had weak spots. One of them was the Oriental Issue, more specifically, how can the nations that wanted to escape from Turkish dominion be stopped, and of course, to see if this was desired.

A potential closing in towards the Straits by Russia, was being looked at with skepticism by London's as well as Wien's decision forums. The fall of the Ottoman Empire was inevitable, so the shock that followed had to have as little effect as possible, as well as the status quo not suffering changes. And so it happened that the so called Concert of Europe was finally crushed by the Oriental problem. In 1854, the Great Powers found themselves fighting each other for the first time after the age of Napoleon. Through an irony of sorts, the Crimean war, which for a long time was considered by historians as an affair that had no sense and could have easily been avoided, was started not by Russia, Great Britain or Austria (countries that had great interest in the Oriental Issue) but by France.

Coming back to the studied time period, we find that this European Concert, which ensured peace for a hundred years, would cease to exist from all points of view. With a blind recklessness, the Great Powers threw themselves into a bipolar world, which consisted of two blocks of power. The starting point is the forging of the alliance between Germany and Austro-Hungary, in 1876, against their two rivals: France and England, which would introduce Germany to the Balkan problem (Cain, 2012). Next comes the signing of the Three Emperors Alliance in 1881, where Russia joins the Germanic countries in a neutrality pact that contained different clauses, also involving the region of south-eastern Europe. By trying to introduce a global policy and a globalization of German foreign affairs, Wilhelm the Second, starts by getting rid of the influential Bismarck in 1890. Once that happens, the alliance system starts to fail. Russia starts getting closer to France, with whom they sign a series of political and military conventions between 1891 and 1894 . 2016/1 Wilhelm the Second's Germany turns its sight towards the Ottoman Empire, and because of its countless economical resources, manages to subjugate the Turkish state into an obvious decay. This event makes Valentin Chirol, the English publicist, write:

"There has never been a great European power that could obtain a position of authority and privilege in a decaying Oriental state, with such fast and apparently little effort, with which its previous bonds and present interests seem so weak." (Chirol, 1903)

Great Britain notices that it has to switch from an "England that has nothing to do with the Balkan area" (Von Eckardstein, 1921) 
status, to a more active presence in the region, one of the reasons being that a potential isolation from the problem would have jeopardized its image of being a Great Power.

At the beginning of the twentieth century, Austro-Hungary and Russia are the Greater Powers that have vital interests in the Balkans. The prestige and influence that they had in the southeastern space are vital points of both empires foreign affairs (Grey,1926). However, the means of action of the two rivals from the Balkans are different. Russia goes through great human and material sacrifices in order to free the Slavs, but it can't gather the fruit its labor because of their involvement in internal affairs of the new states from that area. Austro-Hungary chooses to advance in a more prudent and perseverant way in order to gain an economical supremacy, obtained through the railroad network as well as commercial treaties (Cain, 2012). In April 1897, in Saint Petersburg, the two emperors decide on keeping the status quo in the Balkans. Noel Buxton calls it a delaying policy (Buxton, 1907), both Great Powers postponing solving the Oriental Issue for a decade. The Turkish-Greek war as well as the Cretan revolt had speed up the signing of the treaty. After signing it, during this decade, the relationship between the two empires are extremely cordial (May, 1968). Thus, the Balkan states are affected by this agreement because it diminishes their chances of exerting pressure on the Ottoman Porte, in order to gain advantages that would fit their own national gains.

The small states from south-eastern Europe relied on their foreign policy plan and they came across the Greater Powers' interests. The mirage of territorial expansion is the guiding light of these states policies, and the nationality principle can easily become a source of conflict and discord. The Greater Powers can control the crises that take place in the Balkans by changing political regimes or by marking certain borders, thus crushing their irredentist plans. The next section of the study gradually looks at the way in which the countries from south-east Europe have juggled from a pro-Russian policy to one closer to the Austro-Hungarian Empire's needs.

\section{THE OTTOMAN EMPIRE}

Devlet-i Aliye-i Osmaniye à The Sublime Ottoman State was an imperial super power, manifesting its dominion in the Mediterranean region, and existing from 1299 to 1922 . The decline of this great empire, which in its glory days stretched over a surface of approximately 20 million square $\mathrm{km}$, was accelerated by a series of major economic and political failures. The defeat suffered in front of the Austrian and Polish-Lithuanian allied forces led by Ioan Sobieski at the gates of Wien in 1683 has opened the case of the so 
called “Oriental Issue”. For three hundred years, Greeks, Serbians, Albanians, Egyptians, Syrians and others have caused numerous internal wounds.

The position the greatest forces of Europe had towards the Ottoman Empire became clear at the beginning of the nineteenth century. Russia was the most interested when it came to the "Oriental Issue". The Russian Empire wanted to have control over the Black Sea and obtain access towards the Mediterranean Sea (mainly by occupying Constantinople and the Bosphorus and Dardanelles strays). Russia had a great desire to ensure itself free navigation rights in the region for its commercial and military ships, all while denying these rights to other European forces.

Austria was the power that posed the greatest opposition towards the Russian interests in the Ottoman Empire. Despite the fact that the Hapsburgs have been the greatest enemies of the ottoman people in the past, Austria considered that the threat posed by the Turks at the Danube, was less important than that of the Russians. Austria also feared that the disintegration of the Ottoman Empire would lead to the creation of many national states, which in turn would result in a rise of nationalism amongst the ethnicities from the empire. Because of all these reasons, Austria made keeping unity in the Ottoman Empire one of its main priorities.

Starting with 1876, the helm of the country would belong to Abdul Hamid the Second, who had an autocratic control over a state fractured by internal problems. Despite his conservatism and his belief in absolutist monarchy, Abdul Hamid was responsible for modernizing (in a small part) the Empire during his long reign. The bureaucratic reform, the ambitious Hijaz railway project, the establishment of a registry system for the population and a press control system, are some of the accomplishments of the $34^{\text {th }}$ sultan of the Empire. Regarding his foreign image, he was considered to be extremely cunning, skillful and flexible, being famous for the way in which he was sawing discord among others. (Ghyka, 2004) The sultan has continuously sent signals towards the Great Powers, in order to create a balance between Ottoman interests and the changes that took place on the international scene. A skillful diplomat, Abdul Hamid the Second tried to limit the threats addressed at the integrity of the Ottoman territory by relying on inciting one power over the other, without even striking a deal with one group or another. This policy, which was called divide et impera, was meant to pit the small Balkan states against each other and to draw capital as a result of "mutual jealousies between the Great Forces of Europe" (Cain, 2012).

Being vulnerable and weak from a military point of view, the High Porte had to strengthen its relations with Germany, and a Berlin - Constantinople axe would threaten to cut Europe in half, and thus denying Russia's expansion through the Strays into the 
Mediterranean, and also counter the British interests in Egypt and Persia (Mowat, 1968). The German Imperial family's visit to Constantinople in October 1989 had strengthened this friendship and had alerted the other forces in the event of a possible alliance. This unrest were ultimately pointless, Abdul Hamid the Second not wanting to limit his options by forging an alliance.

The dexterity he showed in the international stage was not the same on a national level. Back home, the Armenian massacre from 1890 , which systematically continued in the century that followed, had led to a failed assassination attempt on the $17^{\text {th }}$ of March, 1905. The major economical problems, poverty, diseases and especially the "Macedonian issue" had inevitably led to the "Young Turk Revolution", which ended a bloody reign, that brought him the name of "The Red Sultan".

The Young Turks was the name of an organization of Ottoman people that were educated in Western universities, who thought that constitutional monarchy would lead to a decrease in social disobedience in the empire. Not even the constitutional period had succeeded in changing the road towards damnation of a once greatly feared empire. The Young Turks could not solve the contradictions between their so called trends of multilateral democratization of a state, which was free from the guardianship of the Greater States, their effective policies on one hand, and the aspirations of the nonTurkish population and the other.

The will of the Balkan states to feast on the European part of the Empire could not be hindered, and so once the "Tripolitan War" started, meaning that the Turks were focused on that area, Serbians, Greeks, Bulgarians and people from Montenegro decided to attack the High Porte.

\section{MONTENEGRO}

Crna Gora à Monte Negro is used when making reference of a larger part of a Montenegro from the fifteenth century. The history of Montenegro is hard to distinguish from that of Serbia. Only after the Ottoman invasion, did things become clearer. In the sixteenth century, Montenegro was attributed a unique form of autonomy inside the Ottoman Empire, by freeing families and clans from that region from certain restrictions. However, the Montenegrins have refused any form Ottoman rule through rebellions and numerous protests, which significantly increased in numbers in the seventeenth century, and culminated with a defeat of the Ottomans in the Great Turkish War at the end of that century. Montenegro became a theocracy, led by the Serbian Orthodox Church and the Metropolitan Church of Montenegro and its Coastline. It was a flourishing period, never before seen since the days of Petrovic Neagos. This theocracy's ruler's name was "Vladika of Montenegro". 
One of the descendants of these bishops was Nikolai the First, which led the country starting with 1860 . Being a minor, he received help from his father Mirko, Great Duke of Gabrovo. The external situation at the time of assuming kingship was as worse as it could get, the Ottomans being on the brink of invading the country. The extraordinary resistance shown by the Montenegrin people (they've barricaded themselves in the capital city of Cetinje) had determined the Great Powers to intervene and ask the Turks to be more flexible concerning peace conditions.

Hard times have come upon this small Balkan state, but after the San Stefano treaty and the Congress of Berlin from 1878, Montenegro became an independent state. This event made the energetic Nikolai the First restart Danilo's reforms (his predecessor) and organize the administrative as well as judicial state. The year 1905 had brought the country's first constitution which guarantied full power to the monarch. This challenge had only succeeded in enhancing the people's lack of faith for the dynasty (Gauthier, 2004).

From a dynastic point of view, Nikolai the First had achieved great success in getting all his five daughters married in an honorable way: the eldest one, Zorka, was married to the future king of Serbia, Peter the First; the second daughter, Milita, to the Great Duke, Peter of Russia; the third, Anastasia, to the Great Duke, Nikolai the First of Russia; the forth daughter, Elena, to the future king of Italy, Victor Emanuel the Third; and lastly, Ana, who was given to Prince Franz Joseph von Batterberg.

In 1910 Montenegro becomes a kingdom, and Nikolai had made the Parliament (which had the same name as in Serbia- Skupstina) give him the title of King. Arrogant by nature and thirsty to quench his ego of creating a stronger kingdom, he took the decision to attack the Ottoman forces on October $8^{\text {th }} 1912$, thus setting off the first Balkan War.

\section{SERBIA}

The Obrenovic and Karadjordje families are the most resounding names in Serbia's history. These dynasties have succeeded at the helm of the country at the beginning of the nineteenth century. In his book about the history of the Balkan dynasties, Guy Gaunthier draws attention to the fact that both dynasties had descended from a swine herdsman.

"Let us remember that the swine herdsman profession was highly seen in the Christian Balkans. An animal which was despised by Muslims, pork became the main meal of the people living here, and by consuming it, it became a sign of cultural and religious membership that were proudly claimed". (Gauthier, 2004)

Alexander I Obrenovic becomes king at the age of 12, as a follow up to his father's abdication, Milan the First. The later had left 
this country in agony, on the brink of civil war and with its finances ruined. Thus the Serbians had put their hopes in young Alexander, only to find out he was just continuing the same ruinous policy. In 1893 he claims to come of age and takes the decision of suspending the constitution. Supporting him in this decision was his father, which returned from exile, as well as Austro-Hungarian supporters, like Kristic. On June $10^{\text {th }} 1903$, as a result of a conspiracy, the king and queen were massacred in Belgrade, in their Old Parliament apartments, with their bodies fiercely mutilated by bullets, being thrown out the windows. The French journalist, Gustave Babin, wrote:

"We were once taught to honor heroic assassinations more justified than this one. We're essentially talking about a patriotic assassination. Without speaking about the slaughters being prepared at the Palace, Serbia was in agony, it was doomed, just as the outlaws found within the regal documents, if what had just happened never took place. (Gauthier, 2004)

Through its representative, Peter, the Karadjordjevic Dynasty comes back at the helm of the country after 44 years. In September 1904, Peter is crowned King of Serbia. Intelligent, cultivated, passionate about history and philosophy, spending a lot of time in exile in Geneva, where he adopted the peaceful ways of the Swiss people, Peter had a Western view for his country. With the help of his radical minister, Pasic, he succeeds in accomplishing a series of reforms in education, commerce and finance, managing to improve the quality of life for the common man.

On the external arena, Peter played the France card, maybe just because he fought in the Franco-Prussian war, where he was also decorated. The economic reliance on Austro-Hungary made Peter call Paris for help, from which the Serbian kingdom applied for loans, even buying a large part of the kettle, bird and fruit production. When it came to his Balkan neighbors, Peter wasn't in the best relationships: the Montenegro territory wanted him to help create a pan-Serbian state, as well as in the case BosniaHerzegovina or of Albania. When it came to the Ottomans, he had many disagreements with them because of the way citizens of Serbian descent were being treated in the Empire. The Bulgarian border was perceived differently by both Peter and Ferdinand the First of Bulgaria. Each of them wanted to expand beyond the other's border.

Three of the Ottoman provinces were now coveted by the Serbians: Albania, Thrace and Macedonia. Bulgaria, Montenegro and Greece also had an interest for the same territories. Only one more step was needed before creating an alliance that led into the first Balkan War. 


\section{GREECE}

At its birth in 1830, Greece occupied a 47.600 square $\mathrm{km}$ area and had a population of 752.000 souls. This country, which was considered an Ottoman Empire enclave, was in fact far from being able to bring together all the territories and people of Hellenic origins. As a consequence, the nationalistic aspirations of the new found kingdom were always being associated with expansionism, which in the Balkan context of those times, would only worry the Great Powers.

Starting with October $31^{\text {st }} 1863$, the crown of the country belonged to Wilhelm de Schleswig-Holstein-SonderburgGlucksburg, future king of the Hellenic people, George the First, son of Christian IX of Denmark and brother-in-law of the Prince of Wales. Because of his origin, it was assumed that his dreams of a Greater Greece would be facilitated by the intervention of George's relatives. Despite all that, any intention of changing the borders inherited after the Independence War, would meet resistance in Paris, London and Wien.

Internally, the endemic political crisis was wreaking havoc, which meant that making a new constitution would have to settle any momentary dissatisfaction. Out of the two chambers that worked under the previous regime, came a new unified chamber, which proclaimed freedom of press, and yet none of these additions would change the political life in Greece.

Three years after coming back into the country, the king is faced with his first international problem, which would impact the state he ruled. The Turkish occupied island of Crete would revolt, due to the way in which the sultan refused to give in to popular pressure. George I does not intervene, despite the fact that all the Greeks united for this patriotic cause.

In 1897, the Cretan problem sets off for a second time. Being embarrassed by the Greater Powers, George I doesn't act at first, but once the fire at Chania takes place, as well as the massacre of thousand of Christians, his attitude tends to change. On April $10^{\text {th }} 1897$, Prince Constantine crosses Thessaly's borders together with his troops, walking into Ottoman territory. The Hellenic army is defeated, a fact confirmed by the signing of the Treaty at Constantinople on December $4^{\text {th }} 1897$.

Years go by, in which the Greek population starts to gather complaints and looks for solutions. Governments come and go, assassinations (Prime-Minister Deliyannis is one of the victims) and crimes are everywhere, while the king spends most of his time in Paris, the people seeing him as a wandering king. As a result, the Cretan, Venizelos, son of a merchant from Mournies, who studied in Athens, appears as a savior to his compatriots. Step by step, he manages to win people's hearts through his ultranationalist 
ideas, being seen at first as an adversary to Prince George (Grand Commissary of an autonomous Crete after the treaty of 1897).

On October $17^{\text {th }} 1910$, King George I names Venizelos Council President, and sets in motion a true personal dictatorship.

Externally, Greece is situated on France's and UK's side, indirectly fighting against Germany and Austro-Hungary, which were true supporters of the High Porte (during the confrontations from 1897 the Turks were receiving stocks of high-tech ammunition from the Krupp Factories as well as tactical advice). As for its relationship with other Balkan countries, we could say that Greece was "alone against all others". Relationships with Romania were extremely sinuous, being often interrupted. The Zappa Affair, as well as Romania's wish to keep the status quo in the Balkans was contradictory to what the Greek side wanted. When dealing with the Ottoman Empire, the number of fights over numbered that of diplomatic discussions, thus closeness between the two wasn't likely in the near future. The differences with Serbia and Bulgaria concerning the position of borders would mean Greece was better keeping a certain distance on a diplomatic scale. That distance would blur once every camp wanted to stomp what was left of the Ottoman Empire.

\section{BULGARIA}

In 1900, Bulgaria had a surface of 96.345 square $\mathrm{km}$ and a population of 3.74 million people, thus being the widest Balkan state (excluding Turkey). The leadership was in the hands of former German prince Ferdinand of Saxa Coburg-Gotha, who became Bulgaria's ruler at July 7 th 1887 , after a favorable vote from Sobrania (Bulgarian Parliament).

Wanting to become a good Bulgarian, Ferdinand let Stambulov govern as he saw fit, a deed which could only favor the good relationship they had. Between September 1887 and May 1894, Bulgaria's Prime Minister, Stambulov, was one the new ruler's confidant. Yet this didn't stay in the way of his decision to get rid of him once Ferdinand understood the politics south of the Danube border. A conservative government takes the place of a liberal one, and the pro-Russian, Zankov, becomes the next Prime Minister. Shortly after this happens, Stambulov is mortally wounded on a street in Sofia.

Externally, Ferdinand perfectly understood that Bulgaria, through its placement in the heart of the Balkans, would be a most wanted ally to the two big powers that had a rivalry in the area at the end of the nineteenth century: Austro-Hungary and Russia. This advantage, as well as the perspectives that came along, offered an unlimited playing field for the prince's personal diplomacy (Gauthier, 2004). Bulgaria always swung between Wien and Saint- 
Petersburg in order to rech the objective the ruler had always craved: full independence and kingship (the Bulgarian Principality being an autonomous state, but not independent). The Prince used the Austro-Russian antagonism in order to free himself from the Porte's tutelage. This moment came at the same time the AustroHungarians took hold of Bosnia and Herzegovina. One day before Franz Joseph declared that the empire had one more province, Ferdinand declares himself king and breaks his bonds with the High Porte (October 5th 1908).

The coordination of the two events gives birth to suspicions because of a previous agreement between Ferdinand of Bulgaria and the leaders of the Habsburg monarchy (Cain, 2012). The official recognition of the new "Czar of Bulgaria" title as well as the country's independence launches new controversies on an international level. Wien and Sofia's decisions impact the balance of power in the Balkan region and create a new diplomatic crisis. In Bucharest, and other places, authorities have an uneasy feeling about this new stage in the Oriental Problem. Russia commences negotiations regarding a new Balkan alliance, taking advantage of the fact that Ferdinand was a friend of their country, and Serbia felt it was directly threatened by Austro-Hungary. The first meeting between Bulgarian and Serbian authorities took place on October $11^{\text {th }} 1911$, and on March $13^{\text {th }} 1912$ the alliance and friendship treaty was signed, containing a secret annex. Once the alliance was made, Ferdinand's dream to restore the Byzantine Empire in its benefit would take shape.

\section{ROMANIA}

The formation of the Romanian nation was a complex one, which sucked the energy of a few consecutive generations of Romanians. The Union of Principalities (January $24^{\text {th }} 1859$ ) and claiming its independence after the war against the High Porte (1877-1878) were the first actual finalized actions that led to the creation of Greater Romania (1918).

King Carol the First was one of the key actors that helped create

Inquiry Carol was named ruler of Romania on May $10^{\text {th }} 1866$. A few months 2016/1 after, the first Romanian constitution is born (June 29 $9^{\text {th }} 1866$ ), which stayed the same until after the First World War (March $29^{\text {th }}$ 1923). In 1878 Carol I of Hohenzollern received the title of "Royal Highness", and the 1886 Constitution replaced the 1881 version, in order to specify among other things, that from that moment on, the head of state will be named King. At the beginning of the twentieth century, the kingdom's political life was based on the two most important parties: The Conservative and Liberal parties. The first represented the interest of the biggest land owners, while the Liberals represented the middle class. On a governmental level, 
these parties were succeeded under the close eye of the king. The later would hold a key role in deciding the result of elections, by virtue of his constitutional prerogatives to name the future Prime Minister.

During the 1899-1907 period, Conservative and Liberal parties, five by number, have rotated without facing any difficulties. In the first years of the new century, governments were "tortured" by a severe economical and financial crisis. The Sturdza government, which was active starting from the beginning of January 1905, managed to revitalize the state and overcome its financial difficulties and even improve the quality of life (especially for the country folk). Sturdza's successor, Gr. Cantacuzino, was put in the ingrate position of hindering the Great Peasant Uprising of 1907, which proved to be the most severe internal crisis since gaining Independence. Amongst these events, the Government is dismissed, and old Sturdza (who reached the venerable age of 74) comes back at the helm of the executive branch for a very short period of time). He was followed by Ionel Bratianu, as leader of Government as well as leader of the National Liberal Party. According to the rotation of parties practice, the end of the four mandatory years of legislative mandate, the King turned his attention towards the Conservatives, resulting in P.P. Carp being named Prime Minister for a second time (he first governed between July 1900 and March 1901).

During the Balkan Wars, Titu Maiorescu is the one that leads Government for two consecutive mandates. A few days before being dismissed (December 31 1913), he presents the Parliament with the famous "Green Card", where the reasons for why Romania had a latent neutrality in the first Balkan War were written, as well as in the case of its full involvement in the second confrontation. Externally, Romania had signed a treaty with the Triple Alliance countries (Italy, Germany, Austro-Hungary) since 1883, but this detail does not mean that the Romanians didn't try a shift between the two blocks.

The importance Romania posed on an international level was also shown by the choice of representatives from great forces to be sent here. Among the ones that can be remembered we can find: Bulow, Goluchowski, Kiderlen, Aerenthal, Czernin, White, Giers Jr. Etc. Bucharest was considered by German diplomacy as the "central observation and estimation point of the entire complex around the Oriental Problem". (Kinderlen, 1925) As I pointed out at the begining of this paper, foreign affairs relied exclusevelly on the monarch's prefferences. A conclusive example is that of Romania, where Carol I chose to forge an alliance with Germany, not only because it was one of the main European Powers of the time, but especially form personal resons, being a descendant of the Hohenzollern-Sigmaringen familly, which was at the helm of 
Germany. Inclining towards the Central Powers had adepts among Conservative and Liberal supporters.

Yet, the efficiency of the 1883 treaty is diminished by its secret caracter. Bismark insisted on this form, in order to avoid certain reactions from Russia, and Romanian diplomats had to agree to it, because of the public opinion's attitute towards Austro-Hungary. In 1888 the treaty was extented for three more years, then it was renewed in 1892 , containing a clause which stated that the treaty would continue to exist until one of the participants would opt out. Nothing would change, concerning this alliance, until the moment Romania decides to enter its first global conflict.

Because of this alliance, the diplomatic ties Romania had with its Balkan neighbors, also coicided with the way those states would get along with Germany and Austro-Hungary. Thus Bulgaria, a faithfull ally of the Czarist Empire, was ploting a future control over the Dobrogea region in Romania. Along these secret wishes, the actions commited by Bulgarians in Macedonia have caused an irritation in Bucharest, where the Macedo-Romanian minority's case was also pleaded by some of its representatives, had a big echo. (Agrigoroaie, 1980) Greece, due to the way it treated MacedoRomanians, was given a cold shoulder on the diplomatic front, leading up to the interuption of diplomatic relations. The Serbian Government tried to get closer to Bulgaria and Russia, as a result of the way Austro-Hungary, an ally of Romania, was treating citizens of Serbian ethnicity. This fact had repercussions on bilateral ties between Romania and the Serbian Kingdom.

France tried to exploit the sympathies of a lot of Romanian politicians, but it couldn't neglect the fact that Romania found itself protected by the Central Powers. Théophile Delcassé, the French foreign affairs minister, would warn Caillaux, the finance minister that:

"The strong political ties that Romania has with Germany and Austro-Hungary, are designed in such a way in which it is of no interest to us to make efforts in order to facilitate financial aid demanded by Bucharest"

(thus referring to the Romanian Government's plea for a loan).

This conviction has continued to influence the conduit of French diplomacy regarding Romania, with Russia having the same attitude. This will change, once the new Foreign Affairs Minister of Russia takes office, Sazonov (1910), who, according to Blondel (French representative in Bucharest):

"Russia sets everything in motion, in order to prepare a favorable future in Romania. (Agrigoroaiei, 1980)

During the Balkan conflicts, the Austro-Hungarian and German diplomatic corps have made visible efforts in order to keep the political orientation of Romania unchanged (official visits, 
loans, etc.). The surface for the Allied Powers' diplomatic actions was largely set in place, through the intervention of new differences that occurred between the allies, which appeared at the same time as the 1908 events aimed at the status quo established at the Berlin Congress. Romania had constantly manifested in favor of maintaining the status quo in the south-eastern region. The situation was relatively favorable for a rise in Franco-Russian influence, but it was countered by an internal event. On January 1991, the Romanian Government was taken over by the Conservatives, with P.P. Carp as Prime Minister and Titu Maiorescu at Foreign Affairs. Both of them were in favor of an alliance with the Central powers.

It can be said that Romania remains a relatively faithful ally to the Central Powers, a faithfulness that actually belonged to a few political circles which were advantaged by the position they held at the top, yet declining in numbers. The conflicts which took place between 1912 and 1913 would also bring along changes within them.

\section{REFERENCES}

Agrigoroaiei Ion, Romania in relatiile internationale 1699-1939, Editura Junimea, Iasi, 1980.

Bulei Ion, Romanii in secolele XIX-XX, Europenizarea, Editura Litera, Bucuresti, 2011.

Buxton Noel, Europe and the Turks, London, 1907. Cain Daniel, Diplomati si diplomatie in sud-estul european: Relatiile ro mano-bulgare la 1900, Editura Academiei Romane, Bucuresti, 2012.

Chirol Valentine, The Middle Eastern Question or Some Political Problems of Indian Defence, London, 1903.

Cotet Paul, Europa, Asia, Editura Didactica si Pedagogica, Bucuresti, 1967.

Gauthier Guy, Acvile si lei- O istorie a monarhiilor balcanice, Editura Humanitas, Bucuresti, 2004.

Ghyka Dimitrie, Memorii, Traducere de Vasile Savin, Institutul European, Iasi, 2004.

Grey Edward- The Viscount Grey of Fallodon, Twenty-Five Years. 1892-1916, vo lume I , London, 1926.

Jones Raymond, The British Diplomatic Service. 1815-1914, Waterloo, Ontario, Wilfried Laurier University Press, 1983.

Kiderlen-Wacher, Der Staatsmann und der Mensch, Volum I, Stuttgart, 1925.

Kissinger Henry, Diplomatia, Editura Bic All, Bucuresti, 2003.

May Arthur, The Habsburg Monarchy. 1867-1914, New York, W.W. Norton, 1968.

McLean Roderick, Royalty and Diplomacy in Europe, 1890-1914, Cambridge, Cambridge University Press, 2001.

Mowat, The New Cambridge Modern History, Volume XII. The Shifting Balance of World Forces, 1898-1945, Cambridge University Press, 1968.

Nye Jr. Joseph, Descifrarea conflictelor internationale- teorie si istorie, Editura An tet XX Press, Filipesti de Padure, 2005.

Vesnitsh Milenko, Diplomacy and Foreingn Policy in Alfred Stead (Ed.), Serbia by the servians, London, 1909.

Von Eckardstein Hermann, Ten Years at the Court of St.James. 1895-1905, London, 1921 
C. Paul-Claudiu

Young George, Diplomacy Old and New, London \& New York, 1921.

Young William, German Diplomatic Relations. 1871-1945, The Wilhelmstrasse and the Formulation of Foreing Policy, New York, iUniverse, 2006. 